\title{
CHERTS WITH MOGANITE IN CONTINENTAL MG-CLAY DEPOSITS: AN EXAMPLE OF "FALSE" MAGADI-TYPE CHERTS, MADRID BASIN, SPAIN
}

\author{
M.A. BUSTILLO \\ Museo Nacional de Ciencias Naturales, CSIC, c/José Gutiérrez, Abascal 2, Madrid 28006, Spain \\ e-mail: abustillo@mncn.csic.es
}

\begin{abstract}
During the Miocene the Madrid basin was a closed basin in which a succession of alluvial and lake deposits were replaced by different types of crusts (mainly calcretes, dolocretes, and silcretes). In a geographically restricted area to the south, Mg-clay deposits were precipitated in ponds on the sand flats. A discontinuous nodular and stratiform Mg-rich chert appears at the top of the Mg-clay deposits and displays visual, mineralogical, and petrological characteristics that are very different from the other silcretes of the Madrid basin.

As revealed by $\mathrm{X}$-ray diffraction, the cherts consist mainly of quartz and moganite, which are commonly found in Magadi-type cherts. The petrological characteristics reveal that the chert consists of a groundmass crossed by several networks of quartz veins. The groundmass is formed by mosaic quartz with different sizes of crystals (usually less than $20 \mu \mathrm{m}$ ) and length-slow chalcedony. The presence of gridwork extinction patterns, the differentiation of silica flakes, and the preservation of the micromorphological characteristics of the Mg-clay deposits indicate an early replacement by quartz and moganite.
\end{abstract}

The quartz networks show veins of different shapes (rectilinear, irregular, branched, and V-shaped), sizes (from a few microns to several millimeters), and textures (mainly megaquartz, microquartz, and length-slow chalcedony). The $\mathrm{V}$-shaped veins, and some irregular and branched veins, are considered to be a consequence of the silicification of cracks in the host rocks. The other veins represent silica filling cracks that formed by shrinkage during the various stages of chert formation.

Many macroscopic attributes (e.g., some kinds of cracks), mineralogical features (the presence of moganite), and petrological characteristics (e.g., rectilinear or gridwork orientation of quartz crystals) are similar to those of Magadi-type cherts. In spite of this, the origin and the environment of formation of this Mg-rich chert, which crystallized by silicification of Mg-clays during deposition of silcrete, are very different from those of the typical Pleistocene Magadi cherts of African lakes. A pronounced shrinkage during silicification in a zone just below the water table and the presence of the moganite are the two factors that caused these Mg-rich cherts to appear similar to Magadi-type cherts.

\section{INTRODUCTION}

During the Miocene, the Madrid basin was a closed basin where the floodplain, palustrine, and shallow-lake deposits were replaced by different types of duricrusts (silcretes, calcretes, dolocretes, and gypcretes). The silcretes are very common, and many petrological types have been described in relation to their mineralogical composition, textures, and host rocks (Bustillo 1976). Lacustrine-palustrine limestones, calcretes, dolocretes, gypsum, and Mg-clay deposits are the host rocks of these groundwater or vadose silcretes (Bustillo 1984; Bustillo and Bustillo 1987; Bustillo and Bustillo 2000). At the south of the Madrid basin, near the villages of Cabañas and Yunclillos (Fig. 1), a special type of silcrete, which is different in composition and textures from all others found in the Madrid basin, is included in Miocene Mg-clay deposits. The two factors that distinguished this silcrete are: (1) the lack of opal, which is present in the other silcretes included in the Mg-clay deposits of the Madrid basin, and (2) the special type of length-slow chalcedony found therein (Bustillo 1976).
In the light of current knowledge concerning new metastable silica phases in cherts (Heaney 1995) and the diagenesis of cherts from Lake Magadi, (Schubel and Simonson 1990), this silcrete displays some features that are similar to Magadi-type cherts, and therefore the Cabañas-Yunclillos chert is an interesting example to study.

Magadi-type chert was first described from the Pleistocene High Magadi beds of Lake Magadi, Kenya (Eugster 1967). This type of chert was subsequently recognized in other regions in the East African Rift zone (Hay 1968) and in the United States (Sheppard and Gude 1986). Magadi-type chert forms from the sodium-silicate precursor, magadiite $\left(\mathrm{NaSi}_{7} \mathrm{O}_{13}(\mathrm{OH})_{3} \cdot 3 \mathrm{H}_{2} \mathrm{O}\right)$, although other sodium silicates such as kenyaite $\left(\mathrm{Na}_{2} \mathrm{Si}_{22} \mathrm{O}_{41}(\mathrm{OH})_{8} \cdot 6 \mathrm{H}_{2} \mathrm{O}\right)$ (Eugster 1967) or makatite $\mathrm{Na}_{2} \mathrm{Si}_{4} \mathrm{O}_{8}(\mathrm{OH})_{2} \cdot 4 \mathrm{H}_{2} \mathrm{O}$ ) (Sheppard et al. 1970) may also be involved.

The mechanism of the conversion process remains a matter of debate. Eugster $(1967,1969)$ suggested that leaching of $\mathrm{Na}^{+}$by percolating waters might cause the transformation, whereas Hay (1970) proposed that a decrease in the activity of silica in solutions in contact with magadiite promotes its conversion to chert. Sheppard and Gude (1986) discuss other possibilities, considering the conversion to be rapid because magadiite has not been reported from lacustrine deposits older than late Pleistocene. Recently, Heaney (1995) reexamined Magadi-type cherts from the collections of H.P. Eugster and R.A. Sheppard by X-ray diffraction and found large amounts of a new silica polymorph named moganite (Flörke et al. 1984). According to Heaney (1995), magadiite diagenetically transforms to quartz through a moganite-rich intermediary phase. References to Magadi-type chert in other parts of the world are very scarce (White and Youngs 1980; Parnell 1985; Houser 1985; Hattori et al. 1996). Therefore, occurrences of chert similar to Magadi-type cherts can provide important new data for use in the identification and clarification of the genesis of these special rocks.

\section{GEOLOGICAL SETTING}

The Madrid basin is an intracratonic basin at the center of the Iberian Peninsula (Fig. 1A). During the Miocene, the area was a closed basin in which a succession of alluvial and lake complexes developed. The sediments of this age have been subdivided into three main stratigraphic units: Lower, Intermediate, and Upper (Alberdi et al. 1984) (Fig. 1B). The Lower Unit consists mainly of evaporite deposits (gypsum, anhydrite, halite, glauberite) and terrigenous sediments; the Intermediate Unit consists of arkosic alluvium, lacustrine carbonates, lutites and gypsum beds; and the Upper Unit consists of fluvial and shallow lacustrine deposits.

The Intermediate Unit (middle Aragonian to early Vallesian) is complex, and its sedimentary facies indicate a shallow lake that was fringed by arkosic alluvium, litharenic alluvial fans, and alluvial fans dominated distally by large floodplains (Calvo et al. 1989). In a geographically restricted area (Cabañas de la Sagra-Yunclillos) to the south of the Madrid basin (Fig. 1C), the distal arkosic alluvial facies grade laterally into marginal lake facies. In this area, Mg-clay deposits were precipitated in ponds on the sand flats (García et al. 1990). According to Pozo et al. (1998a), Pozo et al. (1998b) and Pozo et al. (1999), two Mg-rich units can be established in these Mg-clay deposits. The lower Mg-rich unit is composed chiefly of white nodular sepiolite. The upper Mg-rich unit is made up mainly of Mgsmectites, chert, and dolomites, arranged in two sequences that show pedogenic features. The Mg-rich chert examined in this study appears at the top of the upper kerolitic sequence, so named because a kerolite-stevensite 


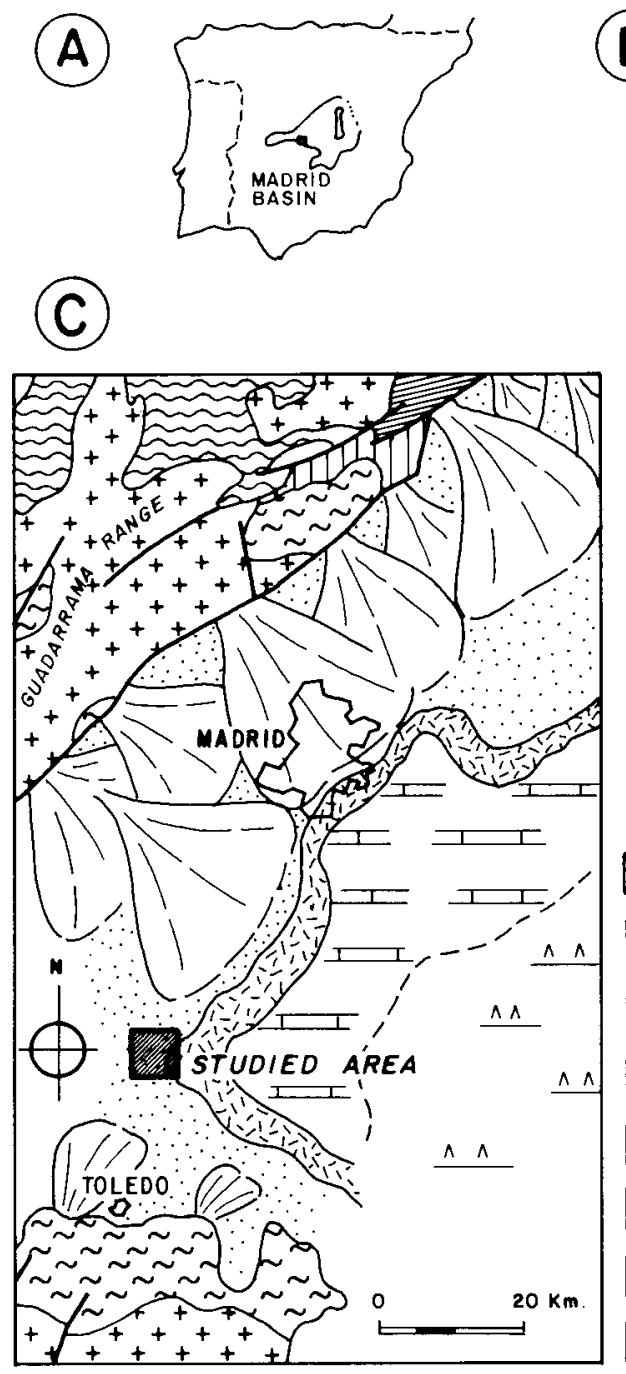

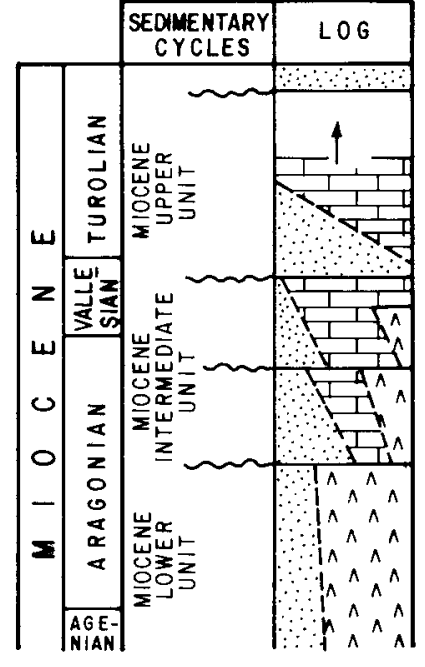

\section{Detrital deposits \\ ILocustrine deposits \\ $\wedge$ Evoporite deposits}

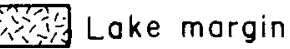

Terrigenous associated to alluvial fan-floodplain facies

Locustrine oreo during the Aragonian

Shales, quartzites and metavulconites

$\approx$ Shales and metagreywackes

$\sim$ Shales, marbles, quartzites and gneisses

$+_{+}^{+}$Plutonic rocks

DII Mesozoic and Paleogene rocks
FIG. 1.-A) Location map and sketch of depositional systems in the Madrid basin during the middle and late Aragonian (after Calvo et al. 1989). B) Generalized stratigraphic section for the Miocene in the Madrid basin. C) Sketch showing the distribution of facies and depositional systems (modified from Calvo et al. 1989). mixed-layer clay is found in association with the other Mg-clays (Pozo et al. 1998a; Pozo et al. 1999).

The Mg-rich cherts are included in white brecciated mudstones and show variable shapes. They are found as isolated nodules, amoeba-like shaped bodies, and discontinuous stratiform layers or crusts (Fig. 2A), with a thickness of up to $3 \mathrm{~m}$. Thin beds ( $0.10 \mathrm{~m}$ in thickness) are locally observed. The interior regions of these cherts are dense and blue-gray in color, but the outer parts are white and generally exhibit many cavities (Fig. 2B). These cavities are a consequence of the present-day erosion of the clays from the host rocks. The network of quartz veins that constitutes the outer part of the chert crust remains unaltered. In places, the chert displays surface reticulation and internal cracks (Fig. 2C), caused by shrinkage.

\section{METHODOLOGY}

Mineralogy was determined by X-ray diffraction, using a Philips PV1710 diffractometer. Textures and mineralogy were studied with a polarized-light microscope and a scanning electron microscope (SEM, Philips KL-20) equipped with an energy dispersive X-ray analyzer (EDAX-DX-4i). SEM examination was carried out using both natural surfaces and sections slightly etched by a solution of hydrofluoric acid (30\%). The analyses of the clay fibers using EDAX were only partially successful, owing to the inter- ference from the surrounding quartz. Major oxides (Table 1) were determined by atomic absorption spectrometry.

\section{X-RAY DIFFRACTION CHARACTERISTICS}

$\mathrm{X}$-ray diffraction indicated that all of the cherts consist mainly of quartz. The XRD patterns of the dense blue-gray chert core display differences from those of the white outer part where the quartz veins and relics of host rocks are more abundant. Commonly, the X-ray pattern of the chert core (and in places the outer part) shows weak peaks that are different from those of the quartz, with $d$ spacings of around 4.45, 3.47, 3.11, and 2.88 $\AA$ (Fig. 3A, B). All these peaks, except the one at $3.47 \AA$, have been found in Magadi-type cherts and were interpreted as an unidentified silica phase (Sheppard and Gude 1986). These peaks are now considered typical of the silica polymorph moganite, which awaits acceptance as an independent mineral species. This polymorph has a widespread distribution in cherts composed of fine-grained quartz and especially in Magadi-type cherts (Heaney and Post 1992; Heaney 1995). The content of moganite in the Mg-rich chert in the kerolitic sequence (taking into account the presence of the clear additional peaks at $3.11 \AA$. and $2.88 \AA$. and their intensity) must be about 15-20 wt. \% for the richest samples. The moganite concentration is lower in the outer part than in the core (Fig. 3A, B). 

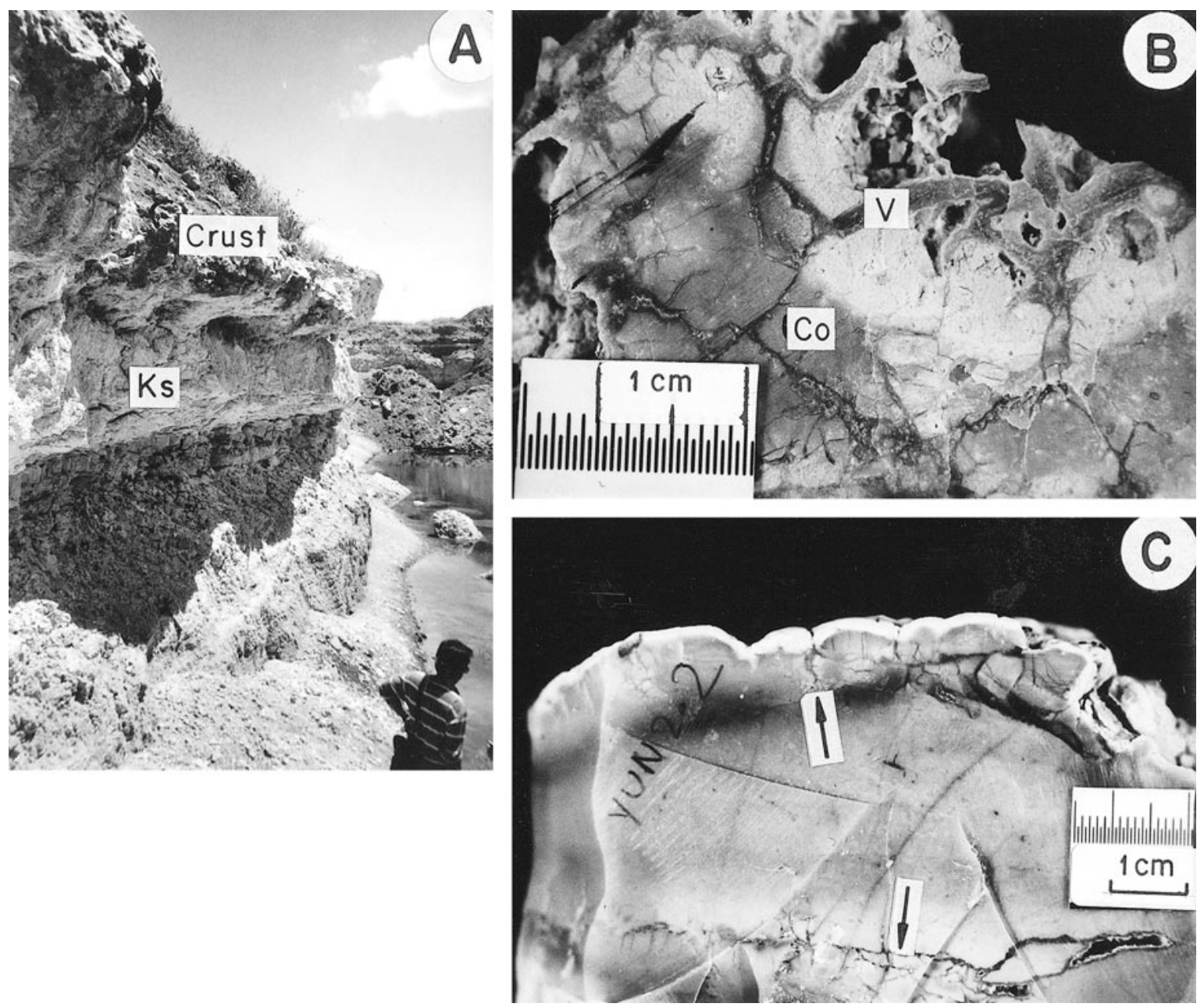

FIg. 2.-A) General view showing the discontinuous stratiform layer of chert (Crust) formed by the juxtaposition of isolated amoeba-shaped bodies and nodules. The crust is included in the Mg-clay deposits of the kerolitic sequence (Ks). B) Detail of a chert. White margins gradually change to the blue-gray core (Co). The quartz veins (V) that formed along previous shrinkage cracks of the host rocks preceded the bulk silicification of the Mg-clay deposits. C) Chert with shrinkage cracks in the surface part and in the core (arrows); they are not merely desiccation cracks at the depositional surface.

The quartz crystallinity index (CI; Murata and Norman 1976) is different for the core (with a CI between 1.2 and 2.6) and the outer shell (with a CI around 5). Because our X-ray diffractometer and standard materials are different from those of Murata and Norman (1976), direct comparison with the results obtained here is not exact. Nevertheless, it is clear that the CIs of the chert core are very low.

TABLE 1.-Chemical composition in weight percent of cherts and host rocks.

\begin{tabular}{|c|c|c|c|c|c|c|c|c|}
\hline & \multicolumn{2}{|c|}{ MGCH-1.3 } & \multicolumn{2}{|c|}{ MGCH-1.7 } & \multicolumn{2}{|c|}{ MGCH-1.8 } & \multirow{2}{*}{$\begin{array}{l}\text { MGC-1.5 } \\
\text { Host-rock }\end{array}$} & \multirow{2}{*}{$\begin{array}{l}\text { MGC-1.6 } \\
\text { Host-rock }\end{array}$} \\
\hline & Core & Outer Part & Core & Outer Part & Core & Outer Part & & \\
\hline $\mathrm{SiO}_{2}$ & 98.20 & 95.60 & 94.85 & 92.00 & 95.70 & 94.05 & 52.15 & 52.30 \\
\hline $\mathrm{TiO}_{2}$ & - & - & - & - & - & - & - & - \\
\hline $\mathrm{Al}_{2} \mathrm{O}_{3}$ & $\operatorname{tr}$ & - & $\operatorname{tr}$ & - & - & - & 2.52 & 1.92 \\
\hline $\mathrm{Fe}_{2} \mathrm{O}_{3}$ & - & - & - & - & - & - & - & - \\
\hline $\mathrm{FeO}$ & - & - & - & - & - & - & - & - \\
\hline $\mathrm{MnO}$ & - & - & - & - & - & - & - & - \\
\hline $\mathrm{MgO}$ & 0.24 & 2.07 & 2.86 & 4.41 & 1.86 & 3.27 & 26.75 & 26.65 \\
\hline $\mathrm{CaO}$ & 0.08 & 0.20 & 0.06 & 0.24 & 0.05 & 0.07 & 0.43 & 0.13 \\
\hline $\mathrm{Na}_{2} \mathrm{O}$ & 0.02 & 0.02 & 0.04 & 0.02 & 0.02 & 0.02 & 0.03 & 0.01 \\
\hline $\mathrm{K}_{2} \mathrm{O}$ & 0.01 & 0.03 & 0.04 & 0.05 & 0.02 & 0.02 & 0.10 & 0.12 \\
\hline $\mathrm{P}_{2} \mathrm{O}_{5}$ & - & - & - & - & - & - & 0.04 & 0.03 \\
\hline $\mathrm{Fe}_{2} \mathrm{O}_{3}$ (total) & - & - & - & - & - & - & 0.46 & 0.46 \\
\hline LOI & 1.46 & 2.06 & 2.13 & 3.28 & 2.36 & 2.53 & 17.31 & 18.14 \\
\hline
\end{tabular}

LOI: Loss on ignition at $1050^{\circ} \mathrm{C}$ tr: traces.
The ratio of the intensities of the 101 peak to the 100 peak for the quartz is also different, and varies from 6 to 7 in the core and from 3 to 5 in the outer part. The values obtained in the core are similar to those of most Magadi-type cherts, which have a ratio between 6 and 8 (Sheppard and Gude 1986). The veins, however, display values (about 4) close to those of typical well-crystallized quartz.

\section{COMPOSITION OF THE CHERTS}

The bulk chemical composition of the cherts is dominated by $\mathrm{SiO}_{2}(92-$ $98 \%)$. The most abundant impurity is $\mathrm{MgO}(0.24-4.41 \%)$ (Table 1$)$. The high $\mathrm{Mg}$ contents are due to the presence of Mg-clays and in some places dolomite. A comparison between the white outer part and the blue-gray inner core of the cherts reveals a larger concentration of impurities in the former. All non-silicon oxides observed in the chert are found in the host rock and are present in lower quantities in the chert. The exception is $\mathrm{Na}_{2} \mathrm{O}$, which is as abundant in the chert as in the host rock. The analyses of typical Magadi-type cherts also do not display significant amounts of $\mathrm{Na}_{2} \mathrm{O}$ (0.07\% at most; Sheppard and Gude 1986).

\section{PETROLOGICAL DESCRIPTION OF THE CHERTS}

The Mg-rich chert fabrics are complex because they reproduce the heterogeneous texture and structure of the massive clays that were silicified. 

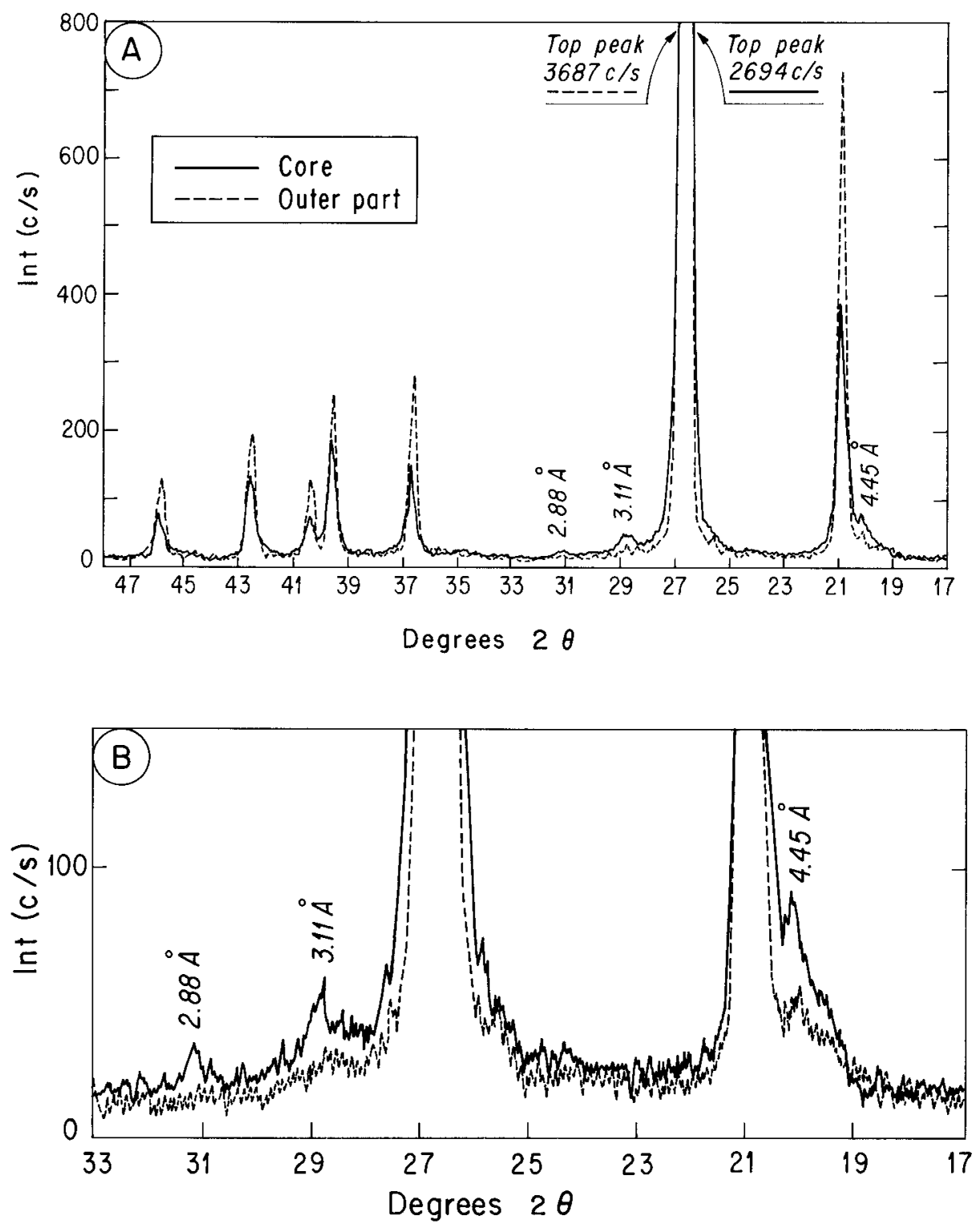

FIG. 3.-A) General X-ray powder diffraction patterns of the core and outer shell of the chert. B) Enlargement of parts of the above diffraction patterns. The chert core presents a higher proportion of moganite than the outer part, and the quartz peaks have less intensity.
The cavities, cracks, cutans, and other soil structures of the mudstones control the silica textures.

Most of the Mg-rich chert samples consist of:

(1) A groundmass formed by mosaic quartz with different sizes of crystals (most less than $20 \mu \mathrm{m}$ ) and length-slow chalcedony (Fig. 4). The spherules of length-slow chalcedony or quartz crystals can appear in isolated points (called "islands of advance" in the general replacement process; Grigor'ev 1965) leaving between them relics of the mudstones (Fig. 4A). In some domains, the groundmass displays gridwork extinction patterns formed by the interlocking aggregation of minute spherules. Flakes similar to clay minerals are in places spread throughout the groundmass to give a general striated parallel birefringence (Fig. 4C). In some samples, the flakes surround the spherules of length-slow chalcedony (Fig. 4B, D). Tiny relicts of the original host mudstone can appear in the groundmass. At the contacts of these patches of host rock, the transition from the mudstone to microquartz or length-slow chalcedony is observed (Fig. 4E, F).

(2) A network of different types of quartz veins crosses the groundmass. The quartz veins correspond to the filling of cavities. The shape is variable: rectilinear (Fig. 5A), irregular, branched (Fig. 5B), and V-shaped (Fig. 5C,
D). In places, these veins isolate zones of groundmass. These veins are filled by different quartz textures, depending on the type of fissure. Megaquartz, microquartz, length-slow chalcedony and parallel nonradiating chalcedony are common. Length-fast chalcedony, however, is found only locally and in minor amounts. A very unusual type of vein, with uniform extinction along it, as in a single crystal (Fig 5A), is observed. In some large veins there are ghosts of the clay cutans of the host rocks (Fig. 5C, D). Flakes that are similar to those found in the groundmass are common between the spherules of length-slow chalcedony that formed the veins or other cements. These flakes (Fig. 4B, D) could be clay minerals or moganite.

Under polarizing-light microscopy, moganite displays a microstructure that is uniformly flaky, spherulitic, or microcrystalline (Flörke et al. 1984; Miehe and Graetsch 1992; Heaney 1995). When it is fibrous, the optical character of elongation is analogous to quartzine and lutecite. Consequently, many of the textures found in the studied chert could be moganite.

As observed by SEM, a massive or flaky structure can be observed in the groundmass, and frequently only Si is detected by EDX spectroscopy. The isolated spots of host-rock relics found in the chert mainly have a 

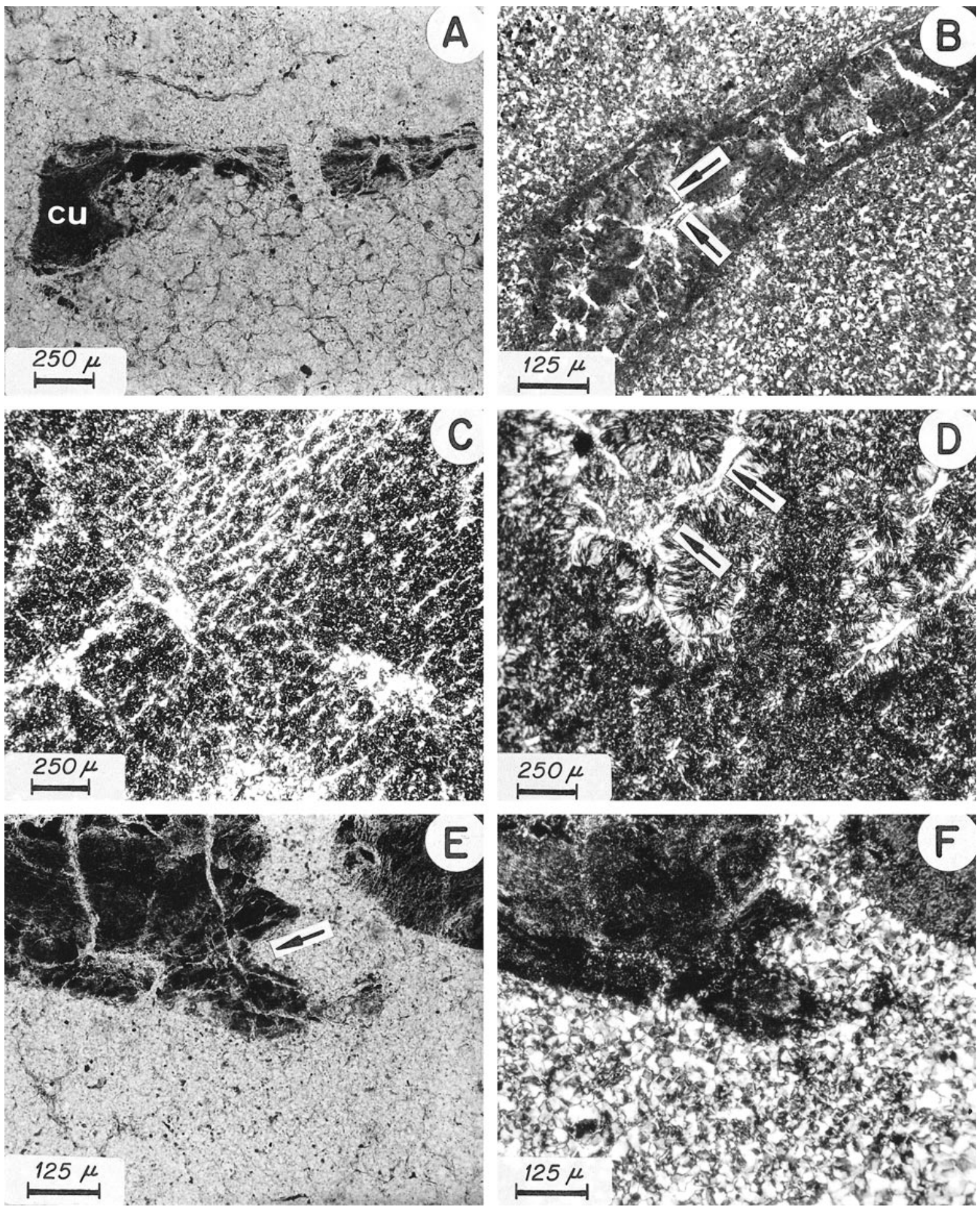

FIG. 4.-Thin sections in the core of the cherts. A) Islands of advance formed by quartz grown in isolated points of the host rock. Clay relics (black threads) remain between the crystals. Clay-rich cutans $(\mathrm{cu})$ exist as relics of the host rocks. Plane-polarized light. B) Chert groundmass with cemented void. In the cemented void, birefringent white flakes (arrows) are found between the spherules of length-slow chalcedony. Crossed nicols. C) Flakes (moganite?) in the groundmass displaying a general striated parallel birefringence, which is not typical of normal cherts. Crossed nicols. D) Flakes (arrows) outlining the spherules of length-slow chalcedony in the groundmass. Crossed nicols. E) Mudstone (darker parts) is a relic of the host rocks included in the chert. The transition from the mudstone to quartz appear to be sharp (arrow). Planepolarized light. F) Similar view, crossed nicols. 

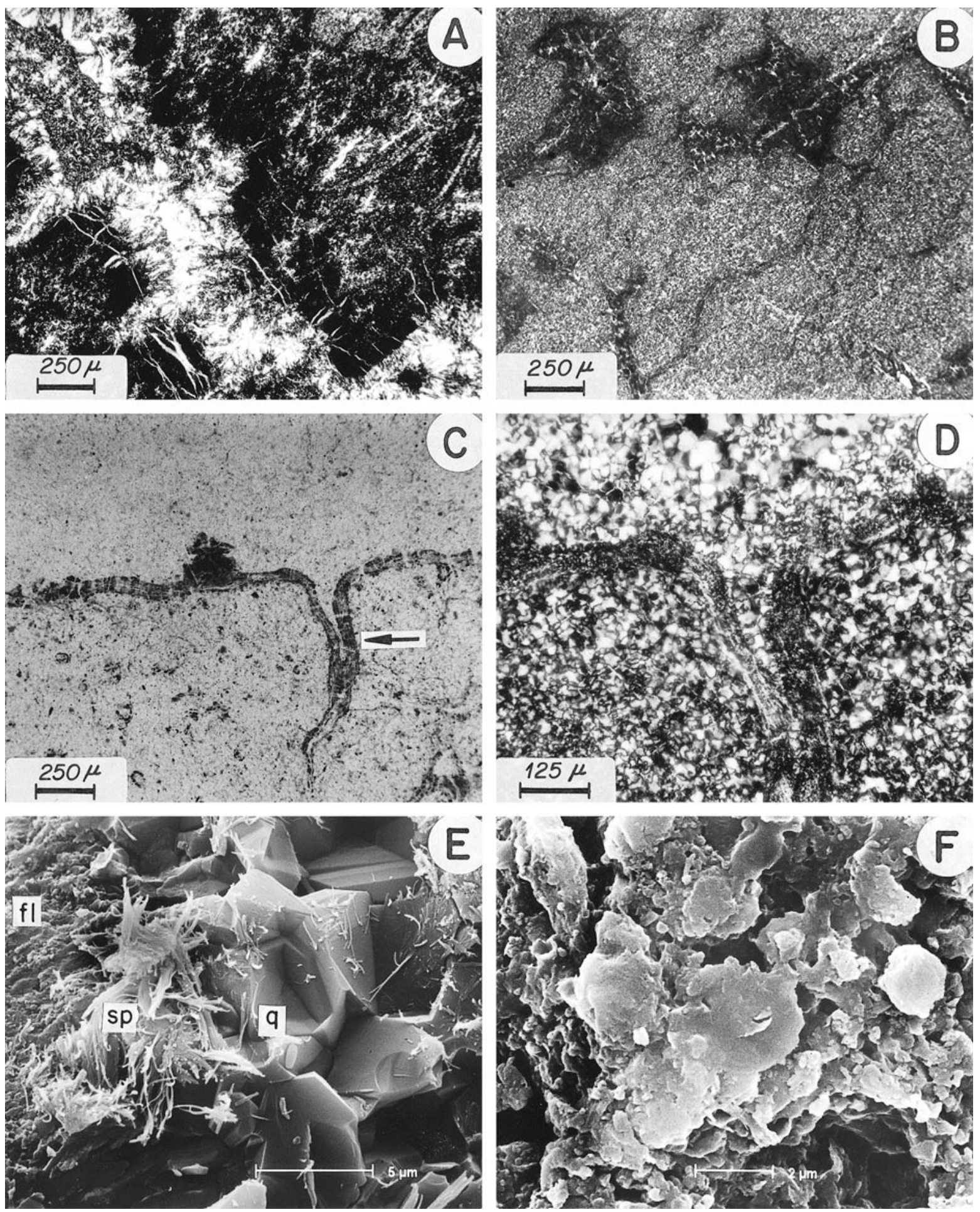

FIG. 5.-Thin sections and SEM pictures in the core of the cherts. A) Groundmass (darker part) and a large filled void (clear part). The void is filled mainly by lengthslow chalcedony (rims and spherules of various sizes) and microquartz. The groundmass adjacent to the cemented cavity is black because it contains more impurities. Thin NW-SE rectilinear veins, with uniform extinction (white), appear in the groundmass that bordered the large filled cavity (easily observed in the black part). These veins could be moganite. Crossed nicols. B) Cemented branched veins and irregular cracks, which isolate blocks of groundmass. Crossed nicols. C) V-shaped crack with remains of clay cutans (arrow). Plane-polarized light. D) Close-up view of Part C. Crossed nicols. E) SEM picture showing the groundmass with flaky structure (fl), a quartz vein (q), and fibers of sepiolite (sp). Only Si was detected by EDX spectroscopy in the groundmass. Mg appeared in the fibers. F) SEM pictures showing plate-like Mg-clays that are found as relics in the chert. 
laminar structure (Fig 5F) and are interpreted as trioctahedral smectites, because they are composed of $\mathrm{Si}$ and $\mathrm{Mg}$. In some veins, fibers that consist of $\mathrm{Si}$ and $\mathrm{Mg}$ are interpreted as sepiolites (Fig 5E).

\section{DISCUSSION}

\section{The Silicification Process and Environments}

The petrological features show that the mudstones display different degrees and stages of silicification. In host rocks that are weakly silicified, silica has penetrated through shrinkage cracks of the host rocks, forming quartz veins that isolate intraclasts and portions of mudstones (Fig. 2B). With further silicification, the remaining parts of the mudstone were replaced by moganite and quartz with various textures, and some of the micromorphological characteristics of the host rock were preserved. Quartz and moganite also cemented the voids, although in some cavities the interstitial fluids were locally rich in $\mathrm{Mg}$ ions and sepiolite precipitated (Fig. $5 \mathrm{E})$.

The observation, in some places, of radial spherules (possibly lengthslow chalcedony) as islands of advance (Fig. 4A) may indicate direct replacement of host rocks by solutions low in silica (Grigor'ev 1965) and in an environment rich in Mg (Folk and Pittman 1971). It is difficult to ascertain whether all the quartz now observed was formed directly or if a moganite precursor existed. The silica flakes surrounding many spherules of length-slow chalcedony in the groundmass and in the cemented quartz voids suggests that these flakes, which do not usually appear in cherts, are now moganite or may have been moganite in the initial silica rock. The lower concentration of moganite in the outer shell of the chert relative to the core is consistent with the depletion of moganite within the weathering rinds of chert nodules observed by Heaney and Post (1992). The recrystallization of the exterior regions of the chert might produce the loss of part of the metastable moganite (Heaney 1995).

The general process of silicification of clays is still a subject of debate. A general question is whether the silica that precipitates is introduced through groundwaters or comes from the destruction of the actual clayey host rock by leaching of the other cations (Thiry and Milnes 1991). At present, no clear features to demonstrate the second hypothesis exist. Phases transitional between the initial clay and the silica phase are rarely found. Meyer and Pena dos Reis (1985), by semiquantitative chemical analyses performed under SEM/EDAX, comment that some palygorskite fibers progressively lose most of their cations and become silica fibers.

In the studied area, the Mg-rich cherts grade laterally to silicified dolomites (Pozo et al. 1998a). The existence of silica-rich ground waters is confirmed because in the Miocene Intermediate Unit limestones, dolostones, and gypsums are pseudomorphed by silica (Bustillo 1976; Bustillo and Bustillo 1987).

The fact that opal does not appear in the Mg-rich chert formed by silicification of clays is significant, because opal is the typical mineral formed during clay replacements (Millot 1970) and it also appears as a ubiquitous component at all sites of silicification of Mg-clays in the Tajo basin (Bustillo 1976). Rayot et al. (1992) consider that under acid conditions the sedimentary clay minerals can be destroyed and the residual silica is organized as opal-CT. In Magadi-type cherts, high $\mathrm{pH}(\geq 9.5)$ causes silica to crystallize as moganite and quartz rather than precipitate as opaline silica. Therefore, high $\mathrm{pH}$ might be the cause of the absence of opal (Hay, personal communication).

The different types of veins mark the various stages of silicification in the $\mathrm{Mg}$-clay deposits. The $\mathrm{V}$-shaped cracks covered with cutans that appear as ghost structures in the cherts (Fig. 5C, D) show that the silicification occurred subsequent to desiccation and formation of soil structures in the $\mathrm{Mg}$-clay deposits that were the host rocks. The silicification fossilized the brecciated host rocks and their cutans. This silicification happened soon after the cracking of the cutans, because there are no fragments of them in the fossilized cemented voids. The branched cavities and the irregular cracks could have existed in the host rocks, but they could also have been formed after silicification and be interpreted as syneresis cracks in the silica rocks.

Length-slow chalcedony, moganite, and neoformed clays (sepiolite detected through SEM observations) (Figs. 4B, 5B, E) in the voids were probably precipitated as cements during the overall silicification, because these textures denote the same Mg-rich environment as the groundmass. The parallel and rectilinear stockworks of unusual microveins, which display uniform birefringence (Fig. 5A), are interpreted to be a consequence of shrinkage due to dewatering of some parts of the chert (Hattori et al. 1996) and are not inherited from the host rocks. All of the above indicate that desiccation took place in the Mg-clay deposits before silicification, and also during and after the formation of the silica rocks. Therefore the silicification occurred in an environment very near to the surface. The preservation of the Mg-clay deposit soil structures in the chert, and the stratiform nature of the nodular chert layers, suggest that the precipitation of silica occurred in a zone just below a shallow water table (Thiry and Milnes 1991).

According to Pozo et al. (1998a) and Pozo et al. (1998b), the initial Mgclay deposits were formed in shallow stagnant waters related to palustrine environments, and under saline, alkaline conditions. Later climatic fluctuations with an increase in aridity caused lake levels to drop, exposing the shallow argillaceous sediments and playas to further pedogenesis. Subsequent introduction of silica by rising ground water, which came from the alluvial fan, led to replacement of the pedogenic Mg-clay deposits and development of extensive stratiform cherts near the upper surface of the groundwater.

\section{Are the Mg-Rich Cherts Magadi-Type Cherts?}

Identification of Magadi-type chert is based upon analysis of visual, petrographic, and X-ray diffraction characteristics (Sheppard and Gude 1986; Schubel and Simonson 1990). In spite of this, classification of post-Pliocene cherts as Magadi-type is frequently difficult because magadiite normally disappears with age and the previously mentioned features are partially lost.

Cherts formed from sodium silicate precursors may inherit two kinds of macroscopic features (Surdam et al. 1972): those caused by soft-sediment deformation of the magadiite stage (folding, lobate protrusions, extrusion forms) and those caused by the large change in volume associated with the conversion of magadiite to chert (surface reticulation cracks, polygonal ridges). In the cherts studied, visual features due to soft-sediment deformation have not been found, but outer and inner cracks are common (Fig. 2B, C).

The textural and petrographic characteristics of the Magadi-type chert and its genetic significance are the following, according to Schubel and Simonson (1990): (1) rectilinear or gridwork orientation of quartz crystals, resulting from retention of preferred crystallographic orientation of the spherulitic aggregates of plate-like crystals of magadiite, (2) inward-directed shrinkage and fenestral cracks formed by volume reduction when magadiite is converted into quartz, through expulsion of sodium and water, and (3) large crystal molds created by dissolution of associated saline minerals.

Of these characteristics, the gridwork extinction pattern and some shrinkage cracks are present in the Mg-chert, but the saline crystal molds are missing. It is significant that in other Magadi-type cherts the evaporite crystal molds do not appear either (Houser 1985). The gridwork extinction pattern is the most distinctive texture of Magadi-type chert, but it is not enough to define it alone (Schubel and Simonson 1990). In the Mg-rich cherts, the microcrystalline groundmass with a rectilinear structure can be explained by: (1) the influence of the shape of the plate-like crystals (Fig. $5 \mathrm{~F}$ ) of the magnesian smectites that were silicified, and (2) the influence of the shape of moganite. The original silica rocks would have contained 
more moganite than is now observed in their composition. Later, the rock was diagenetically transformed to quartzine, as Heaney (1995) suggests, but the original shape was preserved.

The Mg-rich cherts contain moganite and have some characteristics of Magadi-type cherts. Magadiite, however, was not found, as is expected in beds older than late Pleistocene. This could support the hypothesis of Heaney (1995), who explains the frequent association of moganite with "Magadi-type cherts" by suggesting that moganite is a diagenetic alteration product of the hydrous Na-silicate magadiite. The present research indicates that moganite may also form in the silicification of $\mathrm{Mg}$-smectites that include kerolite-stevensite mixed clay layers.

\section{CONCLUDING REMARKS}

Mg-rich cherts have many features in common with Magadi-type cherts and are also found in deposits of alkaline lakes. They share many visual, mineralogical, and petrological characteristics. This similarity is due to the facts that both contain moganite and that both suffered strong shrinkage. In addition, the presence of moganite gives them similar features under Xray diffraction. Irrespective of whether chert is a silica residuum caused by leaching of $\mathrm{Mg}$ from the clay or new silica was introduced from the groundwater, a transformation from Mg-clays to quartz does exist. This transformation implies the expulsion of $\mathrm{Mg}$ and water, and a pronounced shrinkage that could explain the similarity in the cracks of the two cherts.

In spite of this, the process of formation of the Mg-cherts (silcretes formed by replacement of trioctahedral smectites) and the environment in which they were formed (groundwater interface), indicate that their genesis is very different from that of the Pleistocene Magadi-type cherts of the African lakes.

\section{ACKNOWLEDGMENTS}

The research was supported by project PB-98-0668-CO2-01 of the Dirección General de Enseñanza Superior. The paper greatly benefited from critical reviews of Journal referees Richard Hay and Peter Heaney. I thank them for their helpful suggestions and comments.

We are grateful to J. Arroyo, M. Castillejo, J.M. Hontoria, M.I. Pineda, M. Vallejo, and M.C. Sendra of the administrative and technical staff of the Museo Nacional de Ciencias Naturales for their help with various aspects of this work. Thanks to Matthew Harffy for his help in correcting the English version of the manuscript.

\section{REFERENCES}

Alberdi, M.T., Hoyos, M., Junco, F., López Martínez, N., Morales, J., Sesé, C., and Soria, D., 1984, Biostratigraphy and sedimentary evolution of continental Neogene in the Madrid area: Paleobiologie Continentale, v. 14, p. 47-68.

Bustillo, M.A., 1976, Estudio petrológico de las rocas silíceas Miocenas de la Cuenca del Tajo: Estudios Geológicos, v. 32, p. 451-497.

Bustillo, M.A., 1984, Sedimentación lacustre-palustre, formación de opalos y otras silicificaciones en el Mioceno Medio al Sur de Villaluenga (Toledo): Estudios Geológicos, v. 40, p. 137-151.

Bustillo, M.A., AND Bustillo, M., 1987, Contribución al conocimiento petrológico y geoquímico de silcretas formadas por silicificación, (Mioceno, Cuenca del Tajo): Boletin Geológico y Minero, v. 98, p. 238-255.

Bustillo, M.A., And Bustillo M., 2000, Miocene silcretes in argillaceous playa deposits, Madrid basin, Spain: Petrological and geochemical features: Sedimentology, v. 47, p. 1023 1039.

Calvo, J.P., Alonso, A.M., and García del Cura, M.A., 1989, Models of Miocene margin lacustrine sedimentation in the Madrid basin (Central Spain): Palaeogeography, Palaeoclimatology, Palaeoecology, v. 70, p. 194-214.

Eugster, H.P., 1967, Hydrous sodium silicates from Lake Magadi, Kenya: precursors of bedded chert: Science, v. 157 , p. $1177-1180$.

Eugster, H.P., 1969, Inorganic bedded cherts from the Magadi area, Kenya: Contributions to Mineralogy and Petrology, v. 22, p. 1-31.

Flörke, O.W., FlöRKE, U., AND GIESE, U., 1984, Moganite: A new microcrystalline silicamineral: Neues Jahrbuch für Mineralogie, Abhandlungen, v. 149, p. 325-336.

Folk, R., And Pittman, S., 1971, Length-slow chalcedony: a new testament for vanished evaporites: Journal of Sedimentary Petrology, v. 41, p. 1045-1058.

García, E., Brell, J.J., Doval, M., and Navarro, J.V., 1990, Caracterización mineralógica y estratigráfica de las formaciones Neógenas del borde sur de la cuenca del Tajo (Comarca de la Sagra): Boletín Geológico y Minero, v. 101, p. 945-956.

Grigor'Ev, D.P., 1965, Ontogeny of Minerals: Translated from Russian, Israel Program for Scientific Translation, Jerusalem, $250 \mathrm{p}$.

Hattori, I., Umeda, M., Nakagawa, T., and Yamamoto, H., 1996, From chalcedonic chert to quartz chert: diagenesis of chert hosted in a Miocene volcani-sedimentary succession, central Japan: Journal of Sedimentary Research, v. 66, p. 163-174.

HAY, R.L., 1968, Chert and its sodium-silicate precursors in sodium-carbonate lakes of East Africa: Contributions to Mineralogy and Petrology, v. 17, p. 255-274.

HAY, R.L., 1970, Silicate reactions in three lithofacies of a semiarid basin, Olduvai Gorge, Tanzania, in Smith A.A., and Jones, B.B., eds., Mineralogy and Geochemistry of NonMarine evaporites: Mineralogical Society of America, Special Paper 3, p. 237-255.

HEANEY, P.J., 1995, Moganite as an indicator for vanished evaporites: a testament reborn? Journal of Sedimentary Research, v. 65, p. 633-638.

HeAney, P., AND Post, J.E., 1992, The widespread distribution of a novel silica polymorph in microcrystalline quartz varieties: Science, v. 255, p. 441-443.

Houser, B.B., 1985, Magadi-type chert, indicator of a lacustrine environment in the middle Eocene Mcbean Formation, South Carolina: Southeastern Geology, v. 24, p. 185-197.

Meyer, R., and Pena dos Reis, R.B.,1985, Paleosols and alunite silcretes in continental Cenozoic of western Portugal: Journal of Sedimentary Petrology, v. 55, p. 76-85.

Miene, G., AND Graetsch, H., 1992, Crystal structure of moganite: a new structure type for silica: European Journal of Mineralogy, v. 4, p. 693-706.

Millot, G., 1970, Geology of Clays: New York, Springer-Verlag, 499 p.

Murata, K.J., AND NoRman, M.B., 1976, An index of crystallinity for quartz: American Journal of Science, v. 276, p. 1120-1130.

Parnell, J., 1986, Devonian Magadi-type cherts in the Orcadian basin, Scotland: Journal of Sedimentary Petrology, v. 56, p. 495-500.

Pozo, M., Casas, J., and Martín de Vidales, J.L., 1998a, Identification of paleosoil occurrences in paludine $\mathrm{Mg}$-clay deposits. Genetic constrains and evolution of authigenic clays (Neogene, Madrid basin, Spain): 2nd Mediterranean Clay Meeting, Aveiro, Portugal, Proceedings v. 2, p. 145-149.

Pozo, M., Bustillo M.A., Casas J., and Arribas M.E., 1998b, Mg-clay deposits, dolomites and silcretes in palustrine environments (South West of the Madrid basin, Spain)(abstract): International Association of Sedimentologists, 15th International Congress, Abstracts, $\mathrm{p}$ 634.

Pozo, M., Casas, J., Martín de Vidales, J.L., Medina, J.A., and Martín Rubí, J.A., 1999, Características texturales y composicionales en depósitos de arcillas magnesianas de la Cuenca de Madrid. II. Bentonitas (Sector Cabañas de la Sagra-Yunclillos): Boletin Geológico y Minero, v. 110, p. 273-296.

Rayot, V., Self, P., and Thiry, M., 1992, Transition of clay minerals to opal CT during groundwater silicification: Mémoires des Sciences de la Terre, v. 18, p. 47-59.

Schubel, K.A., And Simonson, B.M., 1990, Petrography and diagenesis of cherts from Lake Magadi, Kenya: Journal of Sedimentary Petrology, v. 60, p. 761-776.

ShePpard, R.A., Gude, A.J., AND HAy, R.L., 1970, Makatite, a new hydrous sodium silicate mineral from Lake Magadi, Kenya: American Mineralogist, v. 55, p. 358-356.

ShePpard, R.A., AND GudE, A.J., 1986, Magadi-type chert. A distinctive diagenetic variety from lacustrine deposits, in Mumpton, F.A., ed., Studies in Diagenesis: U.S. Geological Survey, Bulletin 1578, p. 335-345.

Surdam, R.C., Eugster, H.P., and Mariner, R.H., 1972, Magadi-type chert in Jurassic and Eocene to Pleistocene rocks, Wyoming: Geological Society of America, Bulletin, v. 83, p 2261-2266.

Thiry, M., And Milnes, A.R., 1991, Pedogenic and groundwater silcretes at Stuart Creek Opal Field, South Australia: Journal of Sedimentary Petrology, v. 61, p. 111-127.

White, A.H., AND Youngs, B.C., 1980, Cambrian alkali playa-lacustrine sequence in the northeastern officer basin, South Australia: Journal of Sedimentary Petrology, v. 50, p. 1279 1286.

Received 11 February 2000; accepted 23 August 2000 